\title{
Expression of Membrane Fusion Related Genes in Mouse Ovary
}

\author{
Bok-Hae Jung ${ }^{1,3}$, Hyun-Ho Sung ${ }^{2}$, and Chang-Eun Park ${ }^{3}$ \\ ${ }^{1}$ Department of Laboratory Medicine, Pyeongteak International Hospital, Pyeongteak 17821, Korea \\ ${ }^{2}$ Department of Clinical Laboratory Science, Dongnam Health University, Suwon 16328, Korea \\ ${ }^{3}$ Department of Biomedical Laboratory Science, Molecular Diagnostics Research Institute, Namseoul University, Cheonan 31020, Korea
}

\section{마우스 난소에서 막융합 관련 유전자의 발현}

\author{
정복해 ${ }^{1,3}$, 성현호 $^{2}$, 박창은 $^{3}$ \\ ${ }^{1}$ 평택국제병원 진단검사의학과, ${ }^{2}$ 동남보건대학교 임상병리과, ${ }^{3}$ 남서울대학교 임상병리학과 분자진단연구소
}

\begin{abstract}
Granulosa cells surround the oocyte within the ovarian follicle and play an essential role in creating conditions required for oocyte as well as follicular development. The current study was conducted to examine the gene expression profile of mouse ovaries during the primordial to primary follicle transition process. Total RNAs from mouse ovaries on day 5 and day 12 were synthesized cDNA using annealing control primers. The DEGs were cloned and their identities were analyzed by BLAST search. The Plekha5 and Anxa11 were highly expressed in primary follicle stage. By contrast, their expression was increased in granulosa cells at the primary follicle stage. We have successfully discovered a list of genes expressed in day 5 and day 12 ovaries and confirmed that some of them are differentially expressed in PMF and/or PRI. This is a spatial-temporal regulatory mechanism on the ovarian folliculogenesis through membrane fusion. The gene expression profile from the current study would provide insight for future study on the mechanism(s) involved in primordial-primary follicular transition. This will provide information for identification of the mechanism of ovarian dysfunction.
\end{abstract}

Keywords: In situ hybridization, Membrane fusion, Ovarian development

This is an Open Access article distributed under the terms of the Creative Commons Attribution Non-Commercial License (http://creativecommons.org/licenses/by-nc/4.0) which permits unrestricted non-commercial use, distribution, and reproduction in any medium, provided the original work is properly cited.

Copyright (@) 2016 The Korean Society for Clinical Laboratory Science. All rights reserved.

\author{
Corresponding author: Chang-Eun Park \\ Department of Biomedical Laboratory Science, \\ Molecular Diagnostics Research Institute, \\ Namseoul University, 91 Daehak-ro, \\ Seonghwan-eup, Seobuk-gu, Cheonan 31020 , \\ Korea \\ Tel: 82-41-580-2722 \\ Fax: 82-41-580-2932 \\ E-mail: eun2777@hanmail.net
}

Received: January 12, 2016 Revised $1^{\text {st. }}$ January 21, 2016

Revised $2^{\text {nd }}$ : January 21, 2016

Revised $3^{\text {rd }}$ : January 21, 2016

Revised $4^{\text {th }}$ : January 24, 2016

Revised $5^{\text {th }}$ : January 25, 2016

Accepted: January 25, 2016

\section{Introduction}

Mammalian folliculogenesis is a complex process regulated by various extraovarian and intraovarian factors [1]. Despite many studies on the growth and maturation of antral follicles, relatively small numbers of studies have been conducted on early folliculogenesis. Mechanisms responsible for the initiation of follicular growth, also known as primordial follicle activation, are completely unknown.

When ovarian follicles are formed, they enter the resting, primordial stage and the mechanisms of the arrest and initiation of follicular growth of these primordial follicles, also known as primordial follicle activation, are completely unknown [2,3].

At birth, the majority of follicles in mammalian ovaries are arrested at the primordial stage of follicles, and oocytes inside 
follicles are arrested at the diplotene stage of the first prophase.

In vertebrates, the development and function of the ovary is mainly controlled by gonadotropins, follicle-stimulating hormone (FSH) and luteinizing hormone (LH) from the pituitary [4]. However, it is well known that various local factors from the ovary also play important roles in regulating follicle growth and maturation in endocrine, paracrine or autocrine manners [5].

Recently, in the sex determination phase, which relies on the transcription factor GATA- 4 and its cofactor Friend of GATA (FOG2), the subsequent regulation of ovarian differentiation is dependent upon GATA- 4 but not on FOG2. The depletion of the follicular pool in a GATA-4 deficient ovary results in the formation of ovarian cysts and sterility [6].

Therefore, if researchers could compile list of genes and profiles of their expression during early folliculogenesis, particularly at the primordial-primary follicle transition period, it would give insight in order to study the regulating mechanism of this specific process.

Also, the goal for the present study was to investigate differentially expressed genes (DEGs) and their expression pattern that may play important roles in the arrest and/or initiation of primordial follicle growth.

The identification of differential gene expression is possible with the use of powerful tools, such as polymerase chain reaction (PCR) technology controlled by annealing control primer (ACP; Seegene, Seoul, Korea). This primer has a unique tripartite structure with a polydeoxyinosine [poly(dI)] linker between the 3 ' end target core sequence and the 5' end nontarget universal sequence [7].

The ACP linker prevents annealing of the 5' end nontarget sequence to the template and facilitates primer hybridization at the 3 ' end to the target sequence at specific temperatures, resulting in a dramatic improvement in annealing specificity.

This primer with annealing specificity and sensitivity to the template allows only real products to be amplified, such that it enables the researchers to find only real products. We describe the identification of DEGs in day 5- and 12- ovary by using the ACP-PCR method.

The day 1-ovary consists mainly of primordial follicles, while the day 5-ovary consists of primordial and primary follicles, and is devoid of more advanced follicles [8]. Following ACP-PCR, several genes were chosen to confirm their differential expression between day 5 and day 12 ovaries.

To identify differentially expressed genes as well as discover novel genes that may play important roles in primordial to primary follicle transition, we carried out ACP-PCR and to investigate follicular gene expression and the changes during early folliculogenesis.

\section{Materials and Methods}

\section{Source of tissues}

Mice were purchased by Santako Bio Korea (Osan, Korea). Ovaries were collected from day 5 and day 12 neonates for RNA isolation and histological preparation. Animal care and handling was conducted according to the guidelines of the Yong-In University Institutional Animal Care and Use Committee.

\section{2. mRNA isolation and first-strand CDNA synthesis}

Isolation of total RNA from day 5 and day 12 ovary were carried out using Trizol Reagent (Invitrogen, Frederick, MD). The procedure for Total RNA extraction was essentially the same as described previously [9].

The RNA pellet was then washed by adding $75 \%$ ethanol, and centrifuged at 7,500 g for $5 \mathrm{~min}$ at $4^{\circ} \mathrm{C}$. The RNA was dissolved in $0.1 \%$ Diethylpyrocarbonate (DEPC)-water, and the amount was determined by spectrophotometry and then stored at $-70^{\circ} \mathrm{C}$ until use. For genomic DNA removal the total RNA (3 $\mu \mathrm{g}$ ) were treated DNase I (Gibco BRL, Grand Island, $\mathrm{NY}$ ) for $15 \mathrm{~min}$ at $37^{\circ} \mathrm{C}$. For first-strand cDNA synthesis, the reaction was carried out by dT-ACP1, wherein the 3'-end core portion comprises a hybridizing sequence complementary to a poly A region of mRNA transcripts.

Treated total RNA was incubated with $2 \mu \mathrm{L}$ of dT-ACP1 at $80^{\circ} \mathrm{C}$ for 3 min, then reverse transcription (RT) reaction was carried out in $50 \mathrm{mM}$ Tris- $\mathrm{HCl}$ (pH 8.3), $75 \mathrm{mM} \mathrm{KCl}, 3 \mathrm{mM}$ $\mathrm{MgCl}_{2}, 10 \mathrm{mM}$ Dithiothreitol (DTT), $0.5 \mathrm{mM}$ of each dNTPs, 20 U of RNase inhibitor, and 200 U of Superscript III (Invit- 
rogen, Carlsbad, CA). The reaction mixture was incubated at $42^{\circ} \mathrm{C}$ for $90 \mathrm{~min}$, then $94^{\circ} \mathrm{C}$ for $2 \mathrm{~min}$. For PCR amplification, synthesized cDNA was diluted before PCR.

\section{Amplification of cDNA target sequence and cloning}

PCR was conducted using arbitrary ACPs to synthesize second-strand cDNAs under conditions in which the 3'-end core portion of the $\mathrm{dT}-\mathrm{ACP} 2$ is prevented from annealing to the first-strand cDNAs and only the 3'-end core portion of the arbitrary ACP comprising a hybridizing sequence sufficiently complementary to a region of the first-strand cDNAs is involved in annealing to the first-strand cDNAs. A two-ovary amplification reaction was conducted in $20 \mu \mathrm{L}$ reaction mixture comprising $20 \mathrm{mM}$ Tris- $\mathrm{HCl}$ ( $\mathrm{pH} 8.4$ ), $50 \mathrm{mM} \mathrm{KCl}, 2.5$ $\mathrm{mM} \mathrm{MgCl} 2,0.2 \mathrm{mM}$ of each dNTPs, $1 \mu \mathrm{L}$ of arbitary ACP $(5 \mu \mathrm{M})$, $0.5 \mu \mathrm{L}$ of dT-ACP2 $(10 \mu \mathrm{M})$, and $2.5 \mathrm{U}$ of Taq DNA polymerase (Promega, Madison, WI). For the PCR reaction, $1 \mu \mathrm{L}$ of diluted CDNA (1:5) were used as template for each amplification using arbitrary ACP. We used the following PCR conditions: one cycle of $94^{\circ} \mathrm{C}$ for $5 \mathrm{~min}, 50^{\circ} \mathrm{C}$ for $3 \mathrm{~min}$, and $72^{\circ} \mathrm{C}$ for 1 min; followed by 40 cycles of $94^{\circ} \mathrm{C}$ for $40 \mathrm{sec}, 65^{\circ} \mathrm{C}$ for $40 \mathrm{sec}$, $72^{\circ} \mathrm{C}$ for $40 \mathrm{sec}$, and post-extension was done at $72^{\circ} \mathrm{C}$ for 5 min. After PCR, the amplified products were electrophoresed on $2 \%$ agarose gel and stained with ethidium bromide. The differentially expressed bands were extracted with a gel extraction kit (Qiagen, Valencia, CA) and cloned into a TOPO TA cloning vector (Invitrogen), and the cloned DNA was analyzed by sequencing and BLAST search.

\section{Tissue preparation and in situ hybridization}

For histology, ovaries were fixed in 10\% neutral-buffered formalin solution (NBF) for $24 \mathrm{~h}$ at $4^{\circ} \mathrm{C}$, paraffin-embedded, sectioned at $5 \mu \mathrm{m}$ thickness, and mounted on slides. The sections were deparaffinized by two 5 min washes in xylenes and then rehydrated through a graded ethanol series. Next these samples were stained with hematoxylin and eosin for histological observation. Ovaries for in situ hybridization were fixed in $4 \%$ paraformaldehyde in PBS overnight at $4{ }^{\circ} \mathrm{C}$. Paraffin-embedded tissues were cut into $5 \mu \mathrm{m}$ sections, mounted on positively charged slides (ProbeOn Plus, Fisher Scientific, Pittsburgh, PA), and analyzed by in situ hybridi- zation as follows.

Digoxigenin (DIG)-labeled riboprobes of genes were synthesized with the in vitro transcription kit (Promega); the antisense orientation employed SP6 RNA polymerase, and the sense orientation used T7 RNA polymerase along with a DIG RNA labeling mix (Roche, Indianapolis, IN). After incubation at $37^{\circ} \mathrm{C}$ for $6 \mathrm{~h}$, the probes were purified with $\mathrm{G}-50$ columns (Amersham Pharmacia Biotech Ltd., Piscataway, NJ) and diluted with Harland hybridization buffer (50\% formamide, 5X SSC, $1 \mathrm{mg} / \mathrm{mL}$ Torula yeast RNA, $100 \mu \mathrm{g} / \mathrm{mL}$ heparin, $1 \mathrm{X}$ Denhardt's solution, 0.1\% Tween-20, 0.1\% 3-([3-cholamidopropyl] dimethylammonio)-1-propanesulfonate (CHAPS), $0.5 \mathrm{mM}$ EDTA).

Tissue sections were deparaffinized, rehydrated with an ethanol series, and refixed in 4\% paraformaldehyde in PBS for $10 \mathrm{~min}$ to ensure firm attachment of the sections to the slides. Sections were rinsed in $100 \mathrm{mM}$ triethanolamine (TEA) for 5 min, transferred to $100 \mathrm{mM}$ TEA containing $0.25 \%$ acetic anhydride for $10 \mathrm{~min}$, followed by dehydration with an ethanol series and allowed to air dry. Hybridization with the appropriate probe (1:100) was performed overnight at $65^{\circ} \mathrm{C}$. After washing in a 50\% formamide, 2X SSC, $10 \mathrm{mM}$ EDTA solution for $30 \mathrm{~min}$ at $65^{\circ} \mathrm{C}$, sections were blocked for $1 \mathrm{~h}$ in blocking buffer (20\% sheep serum, 2\% nucleic acid) hybridization blocking reagent (Roche) in maleic acid buffer (MAB) (100 mM maleic acid, $150 \mathrm{mM} \mathrm{NaCl}, \mathrm{pH} 7.5)$, then were incubated with anti-DIG alkaline phosphatase-conjugated Fab antibody fragments (anti-DIG-AP, Roche; 1:1000 dilution) for $2 \mathrm{~h}$ at RT. Sections were washed thoroughly with MAB, color produced by incubation for $1 \mathrm{~h}$ at RT with nitro-blue tetrazolium chloride (NBT)/5-bromo-4-chloro-3'-indolyphosphate p-toluidine salt (BCIP) (Sigma-Aldrich Co., St. Louis, MO), then counterstained with Nuclear Fast Red (Dako, Carpinteria, CA). The primer sequence and condition were as follows (Table 1).

\section{Immunohistochemistry}

Ovaries and testis were fixed in $4 \%$ paraformaldehyde, embedded in paraffin, sectioned at $5 \mu \mathrm{m}$ thickness, and mounted on positively charged slides (ProbeOn Plus, Fisher Scientific). Immunohistochemistry was performed as described 
Table 1. Primers sequence and real-time PCR conditions

\begin{tabular}{cclcc}
\hline Gene & Gl No & \multicolumn{1}{c}{ Primer sequence } & Annealing temp. ${ }^{\circ}$ C & Product size, bp \\
\hline Anxa11 & 160707920 & For-AGGTACCATCACTGCTGCTT & 60 & 619 \\
& & Rev-CTCGTTGAAACTGCCACCA & 60 & 556 \\
Plekha5 & 110835705 & For-AAGCATCCGGTTACAGGACA & 60 & 451 \\
G3PDH & 20828350 & Rev-GCACCAGAGCAGCATCTAAC & For-TCCACCACCCTGTTGCTGTA & 60 \\
& & Rev-ACCACAGTCCATGCCATCAC & \\
\hline
\end{tabular}

[10]. Tissue sections were deparaffinized and treated with 3\% $\mathrm{H}_{2} \mathrm{O}_{2}$ in methanol for 20 min to quench endogenous peroxidase activity, preincubated with blocking buffer (Dako, Carpenteria, CA) for $15 \mathrm{~min}$ at room temperature and followed by incubation with a primary antibody (ABIN1037368; Biocompare Inc., CA) against each target.

After incubation for $1 \mathrm{~h}$ at room temperature, the sections were rinsed in PBS, treated for $20 \mathrm{~min}$ at room temperature with a biotinylated secondary antibody (rabbit), then for 20 min at room temperature with a streptavidin-biotin-peroxidase complex. Peroxidase activity was developed with $\mathrm{AEC}^{+}$and hematoxylin was used for counterstaining. In each experiment, control sections were incubated with a dilution buffer lacking the primary antibody.

\section{Results}

\section{Histological examination}

Prior to activation, these immature follicles contain nongrowing oocytes and nondividing, flattened (squamous) pregranulosa cells surrounded by a basal lamina. Following activation, follicle growth begins with the transformation of squamous pregranulosa cells into a single layer of cuboidal granulosa cells surrounding a growing oocyte. The granulosa cells proliferate to form multiple layers, requiring expansion of the basal lamina, and leading to two-layered and multilayered follicle stages. A fluid-filled antral cavity, or antrum, forms in the granulosa cell compartment of the follicle later in folliculogenesis [11].

\section{Typical expression of DEGs, list up by ACP-PCR}

Identifying DEGs exclusively in primordial, primary and secondary follicles may play an important role in the arrest of primordial follicles and/or initiation of their growth into

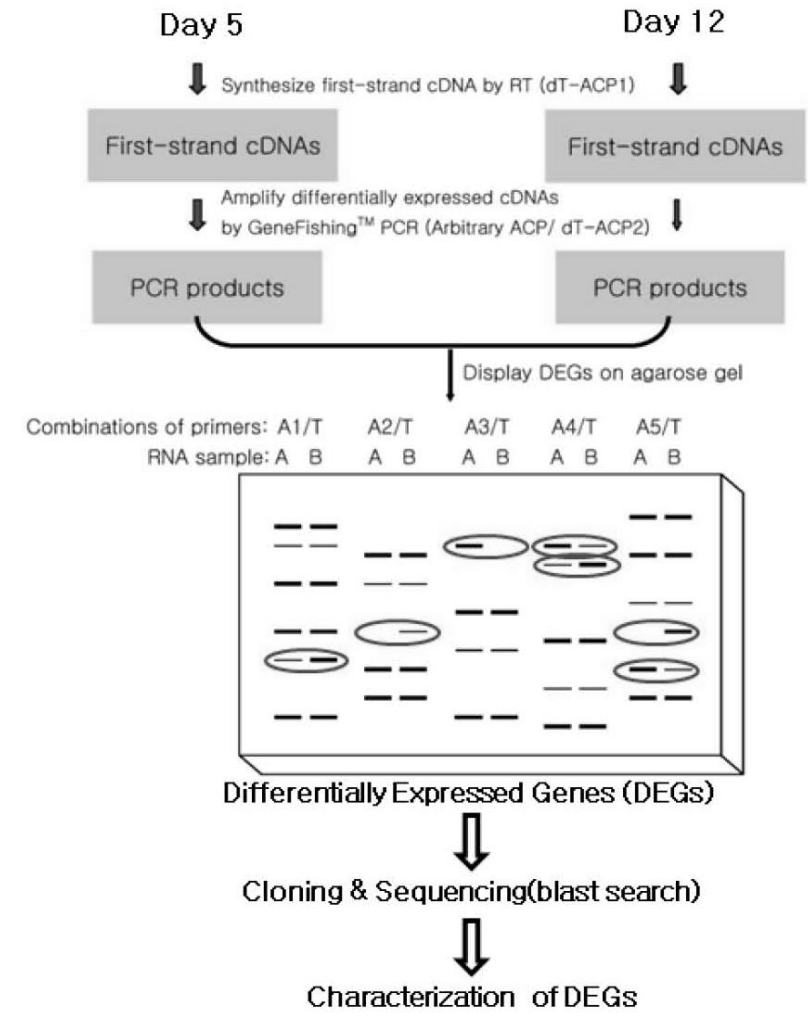

Fig. 1. Schematic representation of processing in this study. Typical expression patterns of DEGs on day 5 and day 12 mouse ovaries by ACP-PCR. RNA samples from day 5 and day 12 ovary were analyzed by using ACPs. Discovered DEGs were processed in cloning, sequencing, characterizing.

primary follicles. The day 5 and day 12 of mouse ovaries acquire cDNA by the same quantity and use ACP to carry out PCR (Fig. 1). Using ACP technology, we isolated differentially expressed bands between day 5 and day 12 ovaries (Fig. 2). Among the DEGs, acquired gene list numbers were between day 5 and day 12 (Table 2).

\section{RNA localization of DEGs by in situ hybridization}

Anxa11 were expressed in oocyte cytoplasm with developmental stage ovaries, and decreases expressed in growing granulosa cells. Plekha5 decreases were expressed in oocyte 
Table 2. Lists of DEGs on the day 5 and day 12 ovaries

\begin{tabular}{clr}
\hline Expression & \multicolumn{1}{c}{ Gene name } & Gi No \\
\hline Day 5 $>$ Day 12 & Annexin A11 (Anxa11) & 160707920 \\
& Pleckstrin homology domain containing, family A member 5 (Plekha5) & 110835705 \\
Day 5 $<$ Day 12 & RING zinc finger protein homolog & 12856802 \\
& Indian hedgehog (I/h) & 31981670 \\
& Transducer of ERBB2, 2 (Tob2), & 108796647 \\
& F-box and WD-40 domain protein 7 (Fbxw 7$)$ & 295293104 \\
& Centrin 2 (Cetn2) & 142368991 \\
& Hepatoma derived growth factor-like 1 (Hdgfl 1) & 254553322 \\
\hline
\end{tabular}

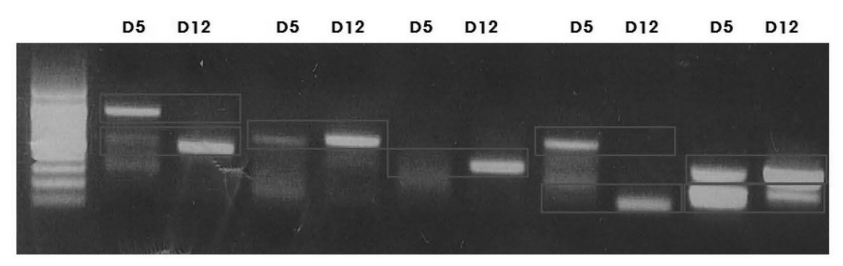

Fig. 2. Typical expression patterns with DEGs in ovary by ACP-PCR. RNA samples from day 5 (D5), The day 12 (D12) were analyzed by using ACPs. The 3 DEGs were highly expressed in day 5 ovary and highly expressed 5 DEGs in day 12 ovary (arrow; 400 bp).

nucleolus in developmental growing follicle stages and granulosa cells were totally expressed in developmental stages.

Using in situ hybridization, the Anxa11 mRNA expression is oocyte nucleolus with primordial follicle in the mouse ovary. Plekha5 mRNA weak expression is oocyte cytoplasmic in the primordial follicle. Therefore, there was increased expression in growing follicles. Further, Granulosa cells increasingly expressed both Anxa11 and Plekha5 in developing follicles (Fig. 3).

\section{Expression of PLEKHA5 protein by immunohistochemistry analysis}

Using the immunohistochemistry analysis, PLEKHA5 protein expressed in oocyte cytoplasm with mouse ovaries at postnatal various stages (Fig. 4). PLEKHA5 protein were expressed in oocyte cytoplasm at all stages from primordial to preovulatory follicles.

\section{Discussion}

This study was a day 5 and day 12 DEGs transcript list obtained by ACP-PCR, respectively. We used day 5 and day 12 whole mouse ovaries for ACP-PCR rather than isolating each
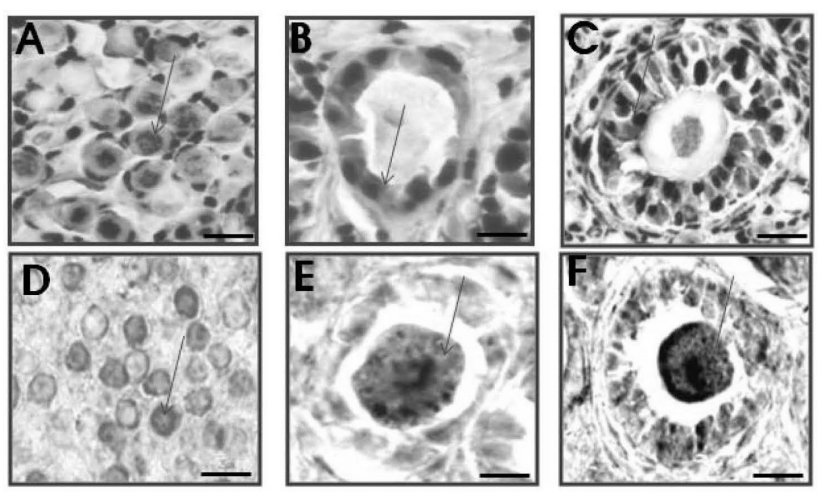

Fig. 3. RNA localization of DEGs in primordial follicle as well as in primary and secondary follicle using the in situ hybridization. A, B, C represented on Plekha5; D, E, F represented on Anxa11. $A$ and $D$ were consisted primordial follicle, $B$ and $E$ were consisted primary follicle, $\mathrm{C}$ and $\mathrm{F}$ were consisted antral follicle. Plekha5 expressed in primordial oocyte and theca cell. But, Anxa11 not expressed in theca cell primordial follicle stage (A, D), Their expression in the granulosa cells increased in the developing follicles (B, C, E, F). ×400, Scale bar; $25 \mu \mathrm{m}$.

follicular stage, since follicles are very small in size and difficult to isolate homogeneous and enough mRNA for ACP-PCR. Of those, they characterized that spatio-temporal localization pattern during the folliculogenesis.

Previously, Cyclin dependent kinase (Cdks) associate with cyclins to form heterodimers that are sequentially activated during the cell cycle [11]. Metazoan cells have multiple Cdks and cyclins that are temporally regulated. In normal cell cycles, Cdk4 and Cdk6 pair with D-type cyclins during G1, Cdk2 pairs with E- and A-type cyclins during S and G2, and Cdk1 pairs with A- and B-type cyclins during G2 and M.

Annexins involved random gene duplications, speciation, and molecular drift in gene structures [12]. Annexin 11 is a $\mathrm{Ca}^{+} /$phospholipid - binding protein that interacts with a member of the S100 protein family, calcyclin (S100A6), in a $\mathrm{Ca}^{+}$-dependent manner [13]. Calcyclin may be involved in 


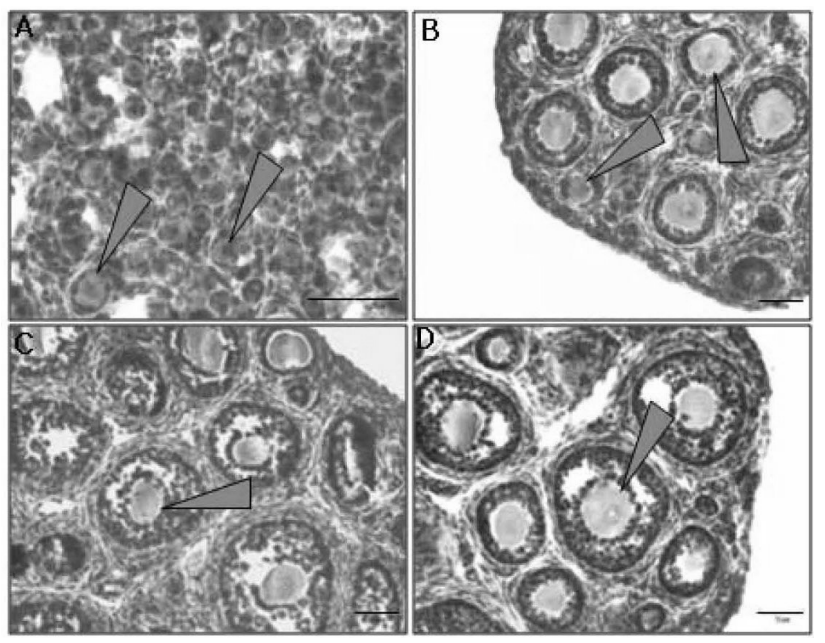

Fig. 4. Immunohistochemistry analysis of PLEKHA5 in the mouse ovaries at postnatal various stages. PLEKHA5 is highly expressed in every oocyte cytoplasm and relatively less in the granulosa cells of the developing follicles. $\times 400$, Scale bar; $50 \mu \mathrm{m}$.

signal transduction of the $\mathrm{Ca}^{+}$induced release of insulin [14,15].

The fork head domain-containing gene family (Fox) comprises over 20 members in mammals and is defined by a conserved 110 amino-acid motif containing a winged helix structure DNA-binding domain. The members of this gene family have been implicated as key regulators of embryogenesis, cell cycling, cell lineage restriction and cancer. The Foxn2 gene is expressed in postgastrulation embryos in multiple tissues that serve as important signaling centers as well as end-stage-differentiated cell types that arise from different germ layers of the developing embryo [16].

Plekha5 (pleckstrin homology domain containing, family A) was gene synonym (Ayu21-9, Gt(pU21)9, Pepp2).

The diffuse B-cell lymphoma (DbI) family guanine nucleotide exchange factors (GEFs) contain a region of sequence similarity consisting of a catalytic Dbl homology (DH) domain in tandem with a pleckstrin homology (PH) domain. The pleckstrin homology domains are protein motifs of approximately 100 amino acids that have been identified in more than 100 molecules involved in signal transduction, including serine/threonine and tyrosine kinases, phospholipases, cytoskeletal proteins, and regulators of small GTPases.

Annexin 11 is one of the 12 vertebrate subfamilies in the annexin superfamily of calcium/phospholipid-binding proteins, distinguishable by long, non-homologous N-termini rich in proline, glycine and tyrosine residues. Several functions have been described for annexins in vitro, including anti-coagulatory and anti-inflammatory activities and involvement in signal transduction, membrane fusion, endo- and exocytosis as well as calcium-channel regulation. However, little is known about their physiological role in vivo.

The annexin possesses an extensive N-terminal region, rich in proline, glycine and tyrosine residues. The N-terminal region of annexin 11 has been proposed to be responsible for its autoantigenicity, nuclear localization and tyrosine phosphorylation. ACP-PCR analysis provides a powerful and rapid means of reconstructing the transcriptome of specific tissues and cell types and for identification of differentially expressed genes.

This study compiled a list of genes specifically expressed during primordial, primary and secondary follicular development. Anxa11 and Plekha5 were one of the stimulators for primordial follicle growth and further development. The characterization and functional analysis of genes in the lists may provide a basis for future studies on the molecular mechanisms of primordial-primary follicle transition, and the development of secondary follicles in mice, as well as in humans.

\section{요 약}

포유류의 난소에서 과립막 세포)는 난포내 난자를 둘러싸고 난 자 뿐만 아니라 난포의 발달에 필요한 상태를 만드는데 중요한 역 할을 한다, 그리고 협막세포 등의 성장과 분화를 조절하는 매우 복 잡한 과정이다. 본 연구의 목적은 성장이 정지되어 있는 원시난포 에서 성장이 개시되는 1 차난포, 2 차난포로 전환하는 동안에 관여 하여 발현하는 유전자를 조사하는 것이다. 본 연구에서는 5일자, 12 일자 난소로부터 총 리보핵산을 추출하여 동량의 RNA로부터 $\mathrm{CDNA}$ 를 합성하여 $\mathrm{ACP}-\mathrm{PCR}$ 을 수행하였다. 서로 다르게 발현하 는 유전자들 (DEGs)을 클로닝과 BLAST를 통한 염기서열 분석하였 다. Anxa11과 Plekha5는 5일자 난소에서 높게 나타났으며 특히 난자핵과 세포질에서 높게 발현하였다. 이에 반해 과립막 세포에서 는 난포발달단계에 따라 증가하는 양상을 보였다. 본 연구에서 성 공적으로 5일, 12 일 난소에서 서로 다르게 발현하는 발현유전자 목 록을 일부 찾아 확인하였다. 이들은 막융합을 통해 난소의 난포발 달과정에서 시간적-공간적인 조절 기전에 의해 이루어 질 것으로 
보인다. 이 유전자 발현 정보는 원시난포의 개시와 성장을 위한 전 환에 관여하는 기전을 이해하는 기초정보와 난소기능부전의 기전 을 규명하는데 정보를 제공할 것으로 기대된다.

\section{Acknowledgements: None \\ Funding: None \\ Conflict of interest: None}

\section{References}

1. Richards JS. Perspective: the ovarian follicle-a perspective in 2001. Endocrinology. 2001;142:2184-2193.

2. Fortune JE, Cushman RA, Kito WS. The primordial to primary follicle transition. Mol Cell Endocrinol. 2000;163:53-60.

3. Fortune JE. The early stages of follicular development: activation of primordial follicles and growth of preantral follicles. Anim Reprod Sci. 2003;78:135-163.

4. Hillier SG. Gonadotropic control of ovarian follicular growth and development. Mol Cell Endocrinol. 2001;179:39-46.

5. Ge W. Intrafollicular paracrine communication in the zebrafish ovary: The state of the art of an emerging model for the study of vertebrate folliculogenesis. Mol Cell Endocrinol. 2005;237: 1-10.

6. Efimenko E, Padua MB, Manuylov NL, Fox SC, Morse DA, Tevosian SG. The transcription factor GATA4 is required for follicular development and normal ovarian function. Dev Biol. 2013;381:144-158.

7. Hwang IT, Kim YJ, Kim SH, Kwak Cl, Gu YY, Chun JY.
Annealing control primer system for improving specificity of PCR amplification. Biotechniques. 2003;35:1180-1184.

8. Durlinger AL, Visser JA, Themmen AP. Regulation of ovarian function: the role of anti-Müllerian hormone. Reproduction. 2002;124:601-609.

9. Park CE, Ko JJ, Lee SH, Cha KY, Kim K, Lee KA. Analysis of the gene expression by laser capture microdissection (II): Differential gene expression between primordial and primary follicles. Dev Reprod. 2002;6:89-96.

10. Park CE, Kim DJ, Hong SN. Expression of mRNAs and Proteins of Cyclin A and LATS Genes in Ovary. Korean J Clin Lab Sci. 2008; $40: 31-40$.

11. Park CE, Hong SN. Expression Patterns of Cell Cycle Related Genes mRNA and Proteins in the Mouse Ovary. Korean J Clin Lab Sci. 2006;38:72-81.

12. Smith PD, Moss SE. Structural evolution of the annexin supergene family. Trends Genet. 1994;10:241-246

13. Toshiki S, Hiroyoshi H. Regulation of calcyclin (S100A6) binding by alternative splicing in the N-terminal regulatory domain of annexin XI isoforms. J Biol Chem. 1998;273:6351-6357.

14. Okazaki K, Niki I, Iino S, Kobayashi S, Hidaka H. A role of calcyclin, a $\mathrm{Ca}^{2+}$-binding protein, on the $\mathrm{Ca}^{2+}$-dependent insulin release from the pancreatic beta cell. J Biol Chem. 1994;269: 6149-6152.

15. Satoshi I, Toshiki S, Tae N, Tatsuya F, Hiroyoshi H, Ichiro N. Annexin XI may be involved in $\mathrm{Ca}^{2+}$-or GTP- $\gamma$ S-induced insulin secretion in the pancreatic $\beta$-cell. FEBS Letters. 2000;479: 46-50.

16. Tribioli C, Robledo RF, Lufkin T. The murine fork head gene Foxn2 is expressed in craniofacial, limb, CNS and somitic tissues during embryogenesis. Mech Dev. 2002;118:161-163. 